\title{
Breivik and Pastine share plans for ACRL
}

\section{By Patricia Senn Breivik and Maureen Pastine}

\section{ACRL's 1994 presidential candidates' statements}

d. note: CERL News offered ACRL candidates for vice-president/president-elect, $\mathrm{Pa}$ tricia Senn Breivik and Maureen Pastine, this opportunity to share their views with the ACRL membership. Although many of the issues and concerns facing ACRL are discussed informally at meetings, this does not provide a national forum available to all members. We hope that providing this forum will assist you in making an informed choice when you receive your ballot from ALA next month.

\section{PATRICIA SENN BREIVIK}

This is the best of times and the worst of times for academic librarians.

National and state attention on information highways and the enhanced access to information made available through technology and networks have captured general public interest in the concerns of our profession to a degree never previously attained. As a consequence, increasing attention is being given by national higher education organizations and accrediting bodies to student use of libraries and other information resources as essential elements in quality undergraduate learning. Yet one has to question what real impact these societal and educational trends are having on business as usual on campuses.

Academic libraries seem to fare no better in resource allocations than previously, and on most campuses little has occurred to enhance the position of librarians within the academic
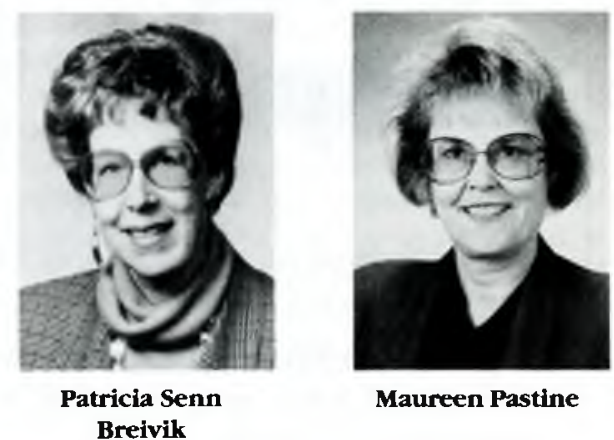

Maureen Pastine

milieu. Indeed, any campus move toward organizational realignments of information resources and services is viewed as a cause of great concern by librarians. Meanwhile, library schools continue to be threatened, and it is increasingly difficult to recruit the calibre and diversity of new professionals to our field as the challenges of the Information Age should seem to command.

The end result of the increasing conflict between the opportunities and the pressing problems confronting the profession could, if we are not careful, result in a defensive posture on the part of academic librarians and ACRL just at the very time our knowledge and expertise are so desperately needed by our academic institutions.

I believe that ACRL needs to assume an uncommonly strong leadership role in the coming years among higher education associations and that it should significantly strengthen membership support which facilitates librarians' leadership roles on their campuses. We must, as an organization, move far beyond practices which led one of our newer members to bemoan when 


\section{Bring the Capitol \\ to your \\ campus.}

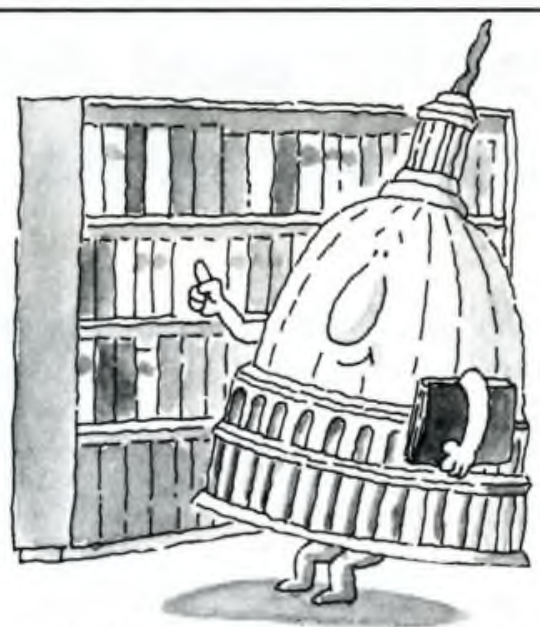

Link your campus to Capitol Hill with Congressional Quarterly publications and services.

The CQ Weekly Report keeps your faculty and students up to date on public policy with objective coverage of each week's congressional action.

The CQ Researcher offers in-depth background, analysis, chronology and bibliographies on one hot topic each week.

With CQ's Washington Alert, your campus has online access to texts of bills, documents, transcripts, CQ publications and much more in 25 fully searchable databases.

Call now for more information on CQ publications and services - and put your campus in the thick of congressional action!

\section{For FREE samples of print publications or information} on CQ's Washington Alert, contact Jana Steiger via the Internet at jsteiger@cqalert.com.

\section{Or call:}

Gigi Hershey at (800) 432-2250 ext. 279, or (202) 887-6279, for print publications.

Waldo Tibbetts at (800) 432-2250 ext. 350, or (202) 887-6350, for CQ's Washington Alert.

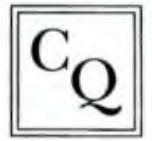

Congressional Quarterly

1414 22nd Street N.W.

Washington, D.C. 20037 
reporting on her first annual conference, "With each day I grew angrier and angrier at the preoccupation with organizational detail" (Library Journal, November 15,1993 , p. 48). We need to respond to that member's challenge to "see beyond the confines of the organization or beyond the way we have always done things." Indeed, we must go on the offensive as an organization. The challenge before ACRL is the same as what faces academic libraries across the country. We must make hard choices because there are not sufficient resources to do all that traditionally has been done plus all that current campus needs would ask of us. If true progress is to be made, we must sacrifice some of the good things we have long done in favor of things that are more important and/or which can better support current educational imperatives.

The outcomes riding on our ability to take the offensive are considerable. Americans have always been enamored of the "quick fix." Technology frequently seems to fit that bill, but it seldom lives up to its promise. Now, unless something changes, the same disappointment is likely to emerge from current hopes for state and national information highways. The problem lies in people not going beyond the glitz of the technology to plan for the information that will be available over the information highways and how people will be empowered to access and effectively use that information.

Who is in a better position than librarians to help their campuses, their regions, and their states avoid making the same shallow and disappointing investments into current network efforts as was made with earlier technological breakthroughs? Of all the information professionals on campuses, librarians have always been the champions of getting the right information to people where and when they needed it and in a manner they could use. With this wonderful heritage, can we do less than step forward to help ensure our campuses' wise use of information resources and technology as tools of empowerment in fulfilling institutional missions? Can ACRL do anything less than work aggressively with other associations to play a similar role at the national level? Can ACRL do anything less than provide continuing education opportunities to facilitate librarians' leadership roles on their campuses and in other nonlibrary associations?

It should be emphasized that I am not suggesting anything that has not always been part and parcel of the best in academic librarianship. In the same issue of Library Joumal quoted earlier, was a 1963 "classic" by Ralph Ellsworth on "The Changing Role of the University Library." In it he stated, "These technological developments will inevitably change the role of the librarian, in that they increase the amount of his individual teaching activities to the point where his role and that of the traditional classroom teacher become indistinguishable." (p. S8)

Ellsworth foresaw current information literacy efforts as now required for campus accreditation by the Commission on Higher Education, the Middle States Association of Colleges and Schools (with the Western Association Accrediting Commission for Senior Colleges and Universities coming quickly behind). The issue is not just bibliographic instruction programs but integration of information resources and technologies throughout the curriculum. This necessitates partnering among librarians and

\section{Can ACRL do anything less than provide continuing education opportunities to facilitate librarians' leadership roles on their campuses?}

classroom faculty for curriculum development as was referenced by Ellsworth and which, of course, echoes ideas as old as the library college movement of the 1930 s. Without such partnering the possibility of future generations of students becoming information literate and, thereby, prepared for lifelong learning-because they can always find the information needed for any issue or problem at hand-is almost nonexistent. Moreover, if our campuses fail at this point, the overall quality of research and the ability of researchers to bring their work into meaningful context will also be diminished.

Nor should we neglect the implications of such leadership partnering for the service dimensions of our institutions. Academic libraries collectively in any state constitute the major body of information that can support broad-based economic development and civic improvement efforts. Librarians need to initiate their campuses' aggressive exploration of how both library resources and the information management expertise of campus librarians can help ensure that the investment in state and 
national information highways "pays off" for their regions.

So how specifically would I work within ACRL if I were elected vice-president/presidentelect? I would use my energy and time to help:

1) build on the efforts of recent years to strengthen ACRL's relationship with other national associations. In particular, I would look for ways to strengthen the work of the Professional Liaison Committee and to encourage and support individual librarians who are actively working in nonlibrary associations;

2) work with accrediting agencies and related groups, such as the College Board, to influence their ways of evaluating library resources and services so as to heighten expectations of the instructional role of academic librarians;

3) change the focus of ACRL's continuing education activities to emphasize areas that can strengthen librarians' leadership roles on campuses and in communities, as well as facilitate the expansion of management responsibilities beyond libraries so as to incorporate areas like academic computing and telecommunications;

4) challenge each and every committee, council, section, and task force of ACRL to assess its activities within and its potential contribution toward the larger educational challenge facing our country, and to reassess their priorities accordingly.

I believe ACRL has fantastic human resources within its membership. I further believe that only if these resources are more effectively focused beyond the boundaries of our profession will our profession prosper. Only then will future generations of students be able to make good use of the information riches which today's technologies make possible, and only then will America be able to maintain a competitive position internationally. I believe our current national and state leaders understand how important information management issues are, but I also believe that without us-the information managers par excellence-little of the good that can happen, will happen.

If ACRL membership is largely content with business as usual, then I am not a good choice for vice-president/president-elect. However, if ACRL's membership believes the time is right for a more externally focused role for the association, then I am a good choice.

My primary job responsibilities as associate vice-president for information resources at Towson State University encompass academic computing, the library, media, and telecommunications. The major focus of my professional efforts for the past five years has been working on behalf of our profession with other national organizations to promote information literacy and resource-based learning. These are the particular strengths I would bring to ACRL along with my burning commitment to the importance of librarians as leaders in today's information society.

\section{MAUREEN PASTINE}

ACRL has been an effective forum for airing issues and concerns within sections, committees, and chapters. It has a major role in being just as effective in provision of resources and revenue to accomplish priorities.

Recently, focus has been on participation in the developing higher education online network and other new technologies. This focus has meant networking with other ALA groups, affiliated professional and scholarly associations and organizations, and other accrediting bodies and information agencies. ACRL programs and committee work have provided for, and will continue to provide for enhanced communications, learning, and networking opportunities for ACRL members.

The issues that ACRL has addressed within the past few years must remain important focus points. They deal with:

- spiraling inflationary costs for serial publications and the need for improved electronic access to full-text and delivery systems;

- improving salaries and establishing pay equity;

- enhancing the librarian's image;

- addressing the issue of education for librarianship;

- searching for ways to improve recruitment into the profession, with a special emphasis on minority groups;

- addressing the needs for expanded continuing education and professional development opportunities;

- serving as the primary voice for the interests of academic and research librarianship;

- becoming more knowledgeable in fundraising and development;

- promoting study, research, and publication relevant to academic and research librarianship; and

- balancing the traditional and new demands and needs of users in academic and research libraries. 
The major question is: What can and should ACRL be doing that is not duplicative of other association work and where can it excel?

The function of libraries and the role of librarians are being redefined by the rapid changes in information technology, increasing competition from external technology-based information services, and diminishing fiscal resources. What is the impact? Greater collaboration by libraries and other information agencies and a redefinition of roles and responsibilities will be needed. One of the greatest challenges will be to balance these needs with available fiscal resources.

Priority issues include coalition building with our many constituencies within and outside of ACRL; marketing what we can do for our membership at the national and state chapters' level; developing greater visibility within other related higher education and subject- or discipline-oriented professional associations. We must continue to demonstrate evidence of responsible decision-making within the existing fiscal reality and assume major roles in information policy and policy decisions facing academic librarianship now and in the upcoming years.

As the nature of information seeking and evaluation becomes increasingly complex in the electronic world, the need for expert staff to provide client-centered services and user education becomes even more essential. An area very seldom addressed is how to work with faculty to reorder teaching/learning/research and develop lifelong learning abilities, transferable from one profession to another.

Another area that needs strengthening is that of ACRL's relationship to international research cooperation. We must support a new nation of learners and provide access to educational services as they need them, when they need them, and wherever they need them. This could be a broad user education program that is based on shared responsibility of librarians and faculty. The new technologies provide a path for greater interactive learning and links to knowledge across discipline or subject boundaries and within a global environment.

The developing new scholarship requires close liaison among librarians, faculty, and students, as well as with other competing information and instructional agencies. ACRL must become highly visible in the rapidly changing public arena of higher education, particularly if academic and research libraries are to be able to compete for increasingly limited resources. We need to recognize the extent and limitations of our collective contributions and focus on increasing access to understanding, not just to information.

ACRL must re-establish priorities. This will mean continual review of the strategic planning documents with an eye to what ACRL can and should be doing. Priorities for ACRL are being hotly debated in leadership, strategic, and visionary planning sessions by all sections, chapters, committees, discussion groups, and roundtables.

\section{The major question is: What can and should ACRL be doing that} is not duplicative of otber asso-

\section{ciation work?}

I am honored to be a candidate for the position of vice-president/president-elect of ACRL. I have been an active member for many years, most recently serving as chair of the International Relations Committee and as representative to the Consortium of Affiliated International Programs, American Association for the Advancement of Science.

If elected to this position I will strive to continue the excellent progress made by past officers on strategic planning priorities and fiscal support issues. I will look forward to the opportunity to work with the ACRL board, section leaders, and members to make significant and positive changes in our profession and in related higher education and subject-oriented professional organizations.

\section{Share your library's news}

CERL News wants to hear about your library's activities. Information in the News from the Field, Grants \& Acquisitions, and People in the News columns is gathered from press releases and notices we receive. If you don't share your ideas and activities with us, we can't share them with CERL News readers. Be sure to put CERL News on your mailing list today. Send notices to the Editor, CGRL News, 50 E. Huron St., Chicago, IL 60611; or e-mail: U38398@uicvm.uic.edu. 


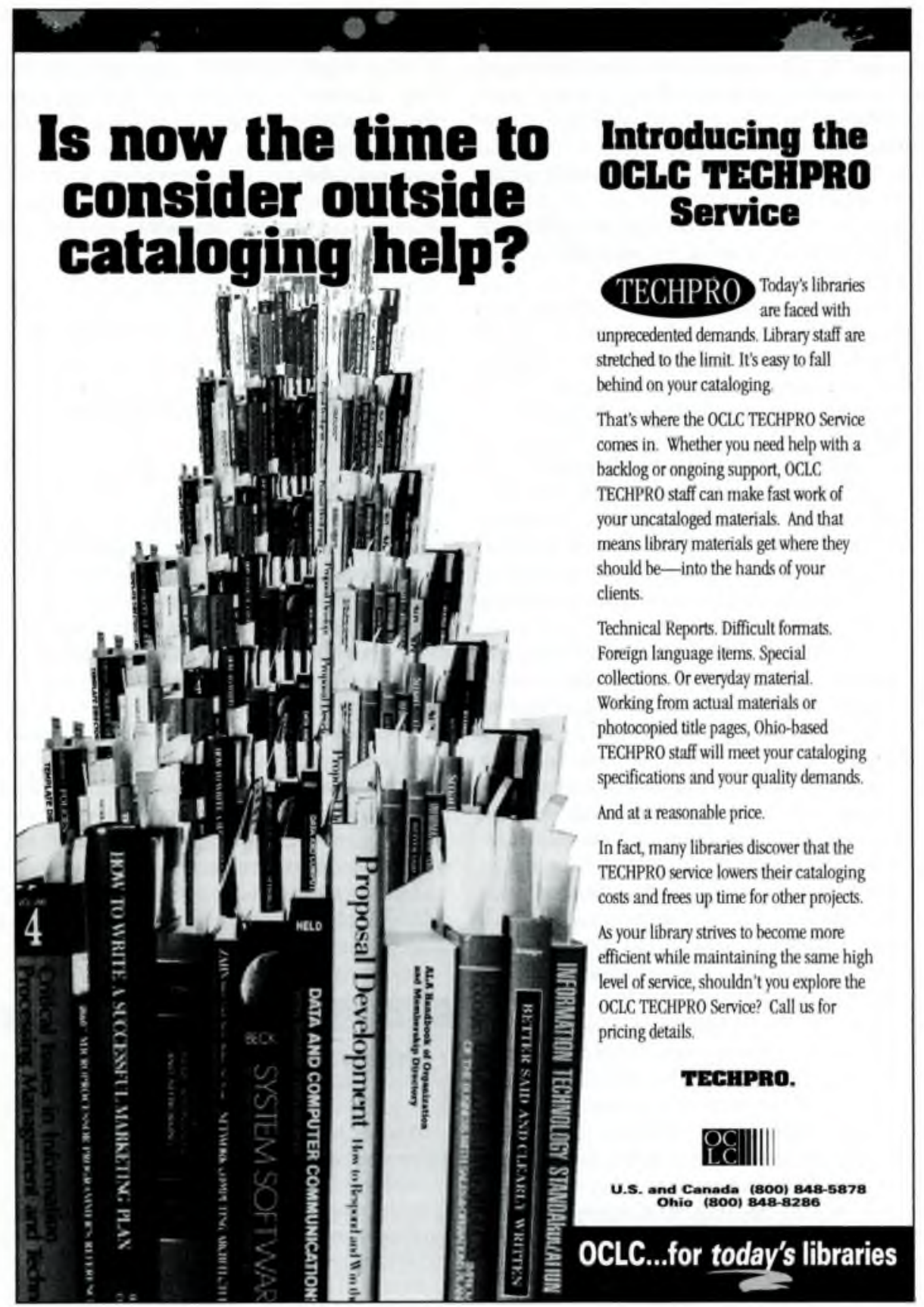

